\title{
Employer Branding Constrains Applicants’ Job Seeking Behaviour?
}

\section{¿Limita la Marca del Empleador la Conducta de Búsqueda de Empleo?}

\author{
Daniel Roque Gomes \\ Esec
}

\author{
José Neves \\ Iscte
}

\begin{abstract}
Researchers have been consistent in advising managers to invest on the organization's employer brand, based on the argument that it will benefit recruitment practice. However, this premise has been majorly sustained following an organizational point of view. As such, the employer branding effects on applicants' job search behavior of applying to a vacancy remains undetermined. Main purpose of this study is to understand if employer branding constrains applicants' job seeking behavior. We propose that applicants develop the desire of submitting to a vacancy through a process having the organizational attributes as its predictor and attractiveness as its mediator. We then investigate if and how employer branding constrains this process, by evaluating its moderating effect. Using confirmatory analysis methodology, we found that employer branding moderates the proposed job seeking process. A positive employer branding has strengthened the process leading to the intention to apply to a vacancy, when compared with neutral or negative employer brandings. This explains applicants' desire of submitting to a vacancy. Based on our results, we suggest directions for practitioners concerning recruitment efficacy.

Keyword: job seeking, employer, branding, applicant, constraints.
\end{abstract}

Resumen. Los investigadores han sido consistentes en el asesoramiento a los directivos de que inviertan en la marca del empleador de la organización, con base en el argumento de que se beneficiará la práctica del reclutamiento. Sin embargo, esta premisa ha sido mayormente sostenida siguiendo un punto de vista organizativo. Como tal, los efectos de marca del empleador sobre el comportamiento de búsqueda de empleo de los candidatos que solicitan una vacante siguen siendo indeterminados. El objetivo principal de este estudio es conocer si la marca del empleador limita la conducta de búsqueda de los solicitantes. Nosotros proponemos que los candidatos desarrollan el deseo de solicitar una vacante a través de un proceso que tiene los atributos de la organización como predictor y el atractivo como su mediador. A continuación, investigamos si y cómo la marca del empleador restringe este proceso, mediante la evaluación de su efecto moderador. Utilizando la metodología de análisis confirmatorio, encontramos que la marca del empleador modera el proceso de búsqueda de trabajo propuesto. Una marca de empleador positiva ha fortalecido el proceso conducente a la intención de solicitar una vacante, en comparación con marcas de empleador neutrales o negativas. Esto explica el deseo de los candidatos de solicitar a una vacante. En base a nuestros resultados, sugerimos recomendaciones a los profesionales, relativas a la eficacia del reclutamiento.

Palabras clave: búsqueda de empleo, empleador, solicitante, marca, limitaciones.

Recruitment is based on a multi-stage process, ultimately aiming to target and to attract prospective employees (Barber, 1998). The issue of efficacy in the attraction stage of recruitment has received considerable attention in the last few years, and it is viewed as a competitive advantage for organizations (Cable \& Turban, 2001; Kickul, 2001). To gather a pool of prospective employees with a highly adjusted profile for the organizations' requirements is an important outcome of any recruitment process (Luce, Barber \& Hillman, 2001).

Correspondence on this article should be sent to Daniel Roque Gómez, Escola Superior de Educação de Coimbra (ESEC) - Praça Heróis do Ultramar - Solum, 3030-3 Coimbra Portugal. E-mail: drmgomes@esec.pt
The organizational attraction thematic has grown significantly in importance under the recruitment remit, mainly due to the attention that researchers have been placing in understanding applicants' attraction to organization. Research on the applicants' perspective on organizational attraction is a clear trend in this field, usually dealing with the contexts and the processes that influence applicants' attitudes and behaviors when they are searching for jobs and deciding on applications (Chapman, Uggerslev, Piasentin \& Jones, 2005; Porter, Cordon \& Barber, 2004; Roberson, Collins \& Oreg, 2005; Van Hooft, Born, Taris \& Van der Flier, 2006).

One of the recent topics under discussion in literature refers to the suggestions that organizations should invest on their employer brand, as several outcomes 
have been associated to organizations that have a positive employer brand (Davies, 2007). However, the effects of employer branding on applicants when they are searching for jobs remains unexplained by existing literature. For these reasons, our main research question is: does employer branding strengthens applicants' attitudes and behaviors regarding an employer organization?

Over the past decade, researchers have made continuous calls for additional research regarding the stage of recruitment where organizations attract applicants, especially over the factors that relate to applicants' job searching decisions (Barber, 1998). One of the most consensually referred topic for this matter, has been the relation between the perceived organizational attributes and several critical job searching indicators, such as attitudes or behavioral intentions, namely, on applicants' reactions regarding an employer (Chapman, Uggerslev, Carroll, Piasentin \& Jones, 2005; Lievens, Van Hoye \& Schreurs, 2005; Williams \& Bauer, 1994) or on predicting their behavioral intentions (AimanSmith, Bauer \& Cable, 2001; Maurer, Howe \& Lee, 1992).

By definition, the organizational attributes refer to a perception of what the organization provides regarding organizational policies and work conditions (Robertson, Collins \& Oreg, 2005). Existing research is consistent in pointing out that aspects as training and compensation, advancement opportunities, or job security policies are related to applicants' positive assessment of organizations (Cable \& Judge, 1994; Kickul, 2001; Taylor \& Bergman, 1987; Thomas \& Wise, 1999; Turban \& Keon, 1993). These attributes have shown to be indicative of actual personnel policies and are relevant for job seekers as clues for developing rational decisions concerning the organization, and to sustain attitudes towards them (Backhaus, Stone \& Heiner, 2002; Jackson, Schuler \& Rivero, 1989). For instance, a solid stream of studies has been assuring that the organizational attributes influence organizational attractiveness, which is regarded as a key outcome for attraction efficacy (Aiman-Smith, Bauer \& Cable, 2001; Bretz, Ash \& Dreher, 1989; Cable \& Judge, 1994; Turban \& Keon, 1993).

By definition, organizational attractiveness refers to the general perceived desirability of a potential work relation with an organization (Aiman-Smith, Bauer \& Cable, 2001), and it is an affective response towards an organization as a place to work. According to Fishbein and Ajzen (1975), an attitude refers to person's placement in an evaluative or affective continuum with respect to an object. Accordingly, attractiveness may be referred to as an important attitude regarding an organization, by addressing a general feeling of favorableness towards it. The attractiveness issue has become gradually more important for recruitment purposes (Lievens, Doncaesteker, Coetsier \& Geirnaert, 2001). Many employers are paying increasing atten- tion to this indicator and to understand ways of how to become more attractive for job seekers. By these reasons, it is faced as an important indicator to be accounted for, when organizations need to attract prospective applicants.

The organizational attributes have also been associated with applicants' job searching behavioral intentions. One frequently mentioned result refers to the organizational attributes predictive abilities over applicants' intention of submitting an application to a vacancy (Aiman-Smith, Bauer \& Cable, 2001; Chapman, Uggerslev, Carroll, Piasentin \& Jones, 2005; Maurer, Howe \& Lee, 1992; Powell, 1984). Social and Organizational Psychologists are clear in assuming that an intention is followed by an action (Albarracín, Fishbein, Johnson \& Muellerleile, 2001). Consequently, this intention should probably result in applicants' actual application behavior. The likeliness of doing so is supported by the correspondence principle of the Theory of Reasoned Action (Fishbein \& Ajzen, 1975), stating that the higher the proximity of the intention to behave with its actual behaviour, the higher its manifestation. By definition, this intention relates to a personal desire to submit an application towards a job vacancy. As such, to determine job seekers' intention to apply is an important resource for organizations, as it will have effects on recruitment's effectiveness.

Several theoretical models certify the importance of the organizational attributes on applicants' job searching outcomes. For instance, Signaling Theory (Spence, 1973) sustains how prospective applicants may draw on clues presented by the organization and uses them to support job searching decision-making processes (Wanous, 1992). Propositions based on this theory suggest that these attributes provide signals of what are the attributes of the organization and this will serve as basis for judgments of applicants. Schneider's (1987) interactionist ASA Model is a recurrently used framework to explain the relevance of the fit between the applicant and the organization for generating outcomes when attracting applicants (Judge \& Cable, 1997; Ryan, Horvath \& Kriska, 2005). In addition, a more cognitive-informationist perspective, who has majorly used the Elaboration Likelihood Model (Petty \& Cacioppo, 1986) framing, has addressed the relevance of having specific information of the organization for diversified attraction outcomes (Highhouse, Stanton \& Reeve, 2004).

When reasoning over these considerations, and in accordance with other researches (Gomes \& Neves, in press), we can conclude that there exists rational guidance to assume the organizational attributes as a predictor of organizational attractiveness, and intention to apply. Also, in accordance with the Theory of Reasoned Action, an attitude should predict behavioral intentions, as such organizational attractiveness should predict job seekers' intention to apply. The first pur- 
pose of this study will be to validate an applicants' job searching process model explaining the intention to apply, in which we support organizational attractiveness acting as mediator of the relation between the organizational attributes and this intention. With the theoretical guidance offered by the Theory of Reasoned Action (Fishbein \& Ajzen, 1975), our first hypothesis is:

H1: prospective applicants will develop an affective response based on the organizational attributes, which ultimately will lead to intention to apply.

According to the above mentioned theoretical frame, our proposal is that the organizational attributes will have the status of informationally-based beliefs regarding the organization, the organizational attractiveness as having the status of attitudes, and the intention to apply as having the status of behavioral intentions. This first hypothesis will allow explaining job seekers' desire of submitting and application to a job vacancy through a process.

The employer branding construct has some of its grounds on the organizational image construct. Organizational Image represents a long-lasting interest of the organizational attraction area of research. This probably relates to evidences suggesting that initial applicants' decisions in recruitment contexts are strongly rooted on general impressions about an organization (Fombrun \& Shanley, 1990; Gatewood, Gowan \& Lautenschlager, 1993; Rynes, Bretz \& Gerhardt, 1991). Organizational image can be broadly understood as a collection of knowledge and feelings about an organization (Tom, 1971), or as the general impressions of an organization held by those outside the same organization (Barber, 1998), being strongly dependent on social cues (Cable \& Yu, 2006). Regarding the content of organizational image, Aiman-Smith, Bauer and Cable (2001) stated that "organization's image may incorporate a number of components, such as corporate citizenship, progressive labor practices, pro-environmental practices" (p.222). Lievens, Van Hoye and Schreurs (2005) suggested that organizational image can be built upon information regarding the size, location, level of centralization, or the geographical dispersion of the organization, and may derive either from snippets of information or from in-depth involvement with it.

The concerns about the content of image have generated a more recent trend of approaching image in the area of organizational attraction and recruitment, and have called the attention for a sophistication of the construct: employer image. Backhaus (2004) suggests that organizations try hard to generate a distinct employer image in job seekers, revealing its "employer brand". The construct of employer brand relates to the knowledge of an organization, based on the promotion of the image of the firm, with the purpose of gen- erating its identity in job seekers. This construct has its conceptual grounds, presumably, in Ambler and Barrow (1996) when they called the attention for the importance of the values and behaviors of organizations towards attracting and retaining prospective employees. It is related with the promotion, of employer dimensions both outside and inside of the organization, having some of its foundations on marketing principles, and applying them for recruitment purposes (Lievens, Van Hoye \& Anseel, 2007).

Following an in-depth qualitative analysis on the way how organizations act in the market as employers, Backhaus (2004) provided a strong advancement on how employer branding can be understood, concluding the existence of several dimensions of this construct, such as: corporate social responsibility; customer orientation; work-family balance. The theoretical fundaments over the importance of the employer branding issue mention that based on diversified dimensions, job seekers will assess the employer brand (Ambler \& Barrow, 1996). It has in its basis the assumption that it brings positive effects on organizational attraction (Ambler \& Barrow, 1996; Collins \& Han, 2004). Accordingly, this notion has been widely accepted by existing research and has lead researchers to suggest that organizations should invest on their employer branding, based on presumable effects on organizational attraction. This suggestion has rapidly gathered wide consensus, especially on a more organizationallyrooted point of view on organizational attraction research.

However, the effects of employer branding on job seekers attitudes and behaviors have not yet been clearly established, as current research does not provide adequate empirical evidences for doing so. It is unknown how or if employer branding constrains applicants' job searching processes. Available evidences only assure the importance of the employer branding issue for organizations and for organizational attraction (Davies, 2007; Mark \& Toelken, 2009). The validation of a theoretical model clarifying if employer branding constrains applicants' decisions when they are searching for jobs is clearly missing. Consequently, the impact of employer branding on prospective applicants' behavioral intentions or attitudes may be misjudged. It represents a pertinent and actual research opportunity that should be addressed as it may bring added-value to existing knowledge.

The core purpose of this study is, therefore, to empirically validate how and if employer branding strengthens applicants' attitudes and behaviors regarding an employer organization. According to this rationale, a positive, neutral, or negative employer branding associations may constrain job seekers process, and so, we regard employer branding as a contextual variable. A positive employer branding should generate a stronger job searching process, when compared with neutral or negative employer branding. 
Bringing the advancements of our reasoning all together, we propose to approach the study of applicants' attraction to organizations, through a model of analysis who integrates both a process and a context for explaining applicants' job searching. This implies validating a theoretical model expecting a moderatedmediation effect (see Preacher, Rucker and Hayes (2007) for additional information regarding the expected effects of a moderated-mediation model). Therefore, our second hypothesis is:

H2: employer branding moderates the mediation effect of attractiveness in the relation between the organizational attributes and intention to apply.

We propose that a positive employer branding generates a stronger process explaining job seekers' desire of submitting an application for a vacancy. Figure 1 show the proposed model of analysis. participating in a study that was meant to understand how organizations are evaluated.

Based on Backhaus employer branding dimensions (2004), three different descriptions were developed in order to build different employer branding conditions (see section 4.2 for employer branding manipulations). Participants were randomly assigned to one of the conditions, and have received an adapted employment advertise to evaluate. According to the three different conditions, three corresponding employer branding groups were formed: positive, neutral, negative.

\section{Employer Branding Manipulation}

Backhaus (2004) suggestions of dimensions of employer branding were taken into account in order to build three organizational employer branding conditions (positive, neutral, negative). Eight dimensions

Figure 2. Theoretical Model

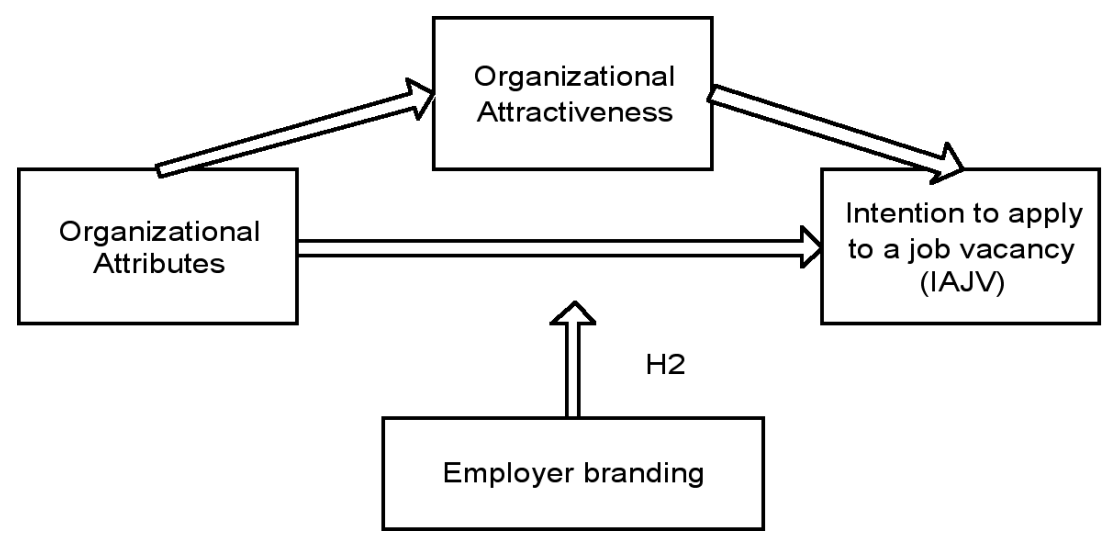

\section{Method}

\section{Participants and Procedure}

Two hundred and eight participants are our sample of the general population of prospective applicants' profile in the Marketing professional field. The sample is composed by one hundred and twelve undergraduate students in Marketing courses from five Universities and ninety six Marketing professionals (45\% of which with more than one prior work experience). Demographic information collected showed that participants had a mean age of 23 years $(\mathrm{SD}=5.58)$ and $59.1 \%$ were women. This sample also integrates participants who referred to be actively searching for a job $(11 \%)$. The construction of the instrument obeyed to criteria in order to control the impact of potential systematic errors (Podsakoff, Mackenzie, Lee \& Podsakoff, 2003). The instructions informed that they were were considered: corporate social responsibility, customer orientation, customer satisfaction, organizational climate, workers' non-work related responsibilities, work-family balance, stakeholders' responsibilities and size. Following these suggestions, descriptions of organizations were built for accessing the different conditions of employer branding.

The description used to manipulate positive and negative employer branding in the dimension of Corporate Social Responsibility is provided as an example: Positive ("We guide our activity over Corporate Social Responsibility aims. We are strongly motivated in enhancing our performances by contributing and acting in the development of our community. We are focused in contributing for a better society.")/ Negative ("Our purposes are on maintaining the functioning of the company. We don't aim for any kind of Corporate Social Responsibility program, as it would scatter our purposes of action"). 


\section{Manipulation pre-test}

The employer branding conditions were tested by an independent pilot study. The items used to evaluate the employer branding conditions were based on Backhaus (2004) $(\alpha=.72)$. One-way ANOVA results indicated significant differences between groups $(F=98.987 ; p=.000)$. Post hoc analysis contrasting each condition was also conducted using Bonferroni comparisons, evidencing significant differences between all conditions. Complementarily, t-tests were performed showing that participants in the positive condition $(\mathrm{N}=20 ; \mathrm{M}=5.98 ; \mathrm{SD}=.54)$ perceived higher levels of employer brand than those in the neutral condition $(\mathrm{N}=20 ; \quad \mathrm{M}=4.72 ; \quad \mathrm{SD}=.84) \quad(t=-5.661$; $p=.000$ ), and than those in the negative condition $(\mathrm{N}=20 ; \quad \mathrm{M}=2.50 ; \mathrm{SD}=.94) \quad(t=-14.344 ; p=.000)$. Participants in the neutral condition differed significantly from the ones in the negative condition $(t=-$ $7.865 ; p=.000)$.

\section{Measures}

Unless otherwise indicated, items were measured using a seven-point scale ranging from 1=Strongly Disagree to $7=$ Strongly Agree.

Organizational attractiveness. Three items used by Bauer and Aiman-Smith (1996), and Highhouse, Lievens and Sinar (2003) were used to build the organizational attractiveness measure. Sample item: "This would be a good company to work for".

Intention to apply to a job vacancy. Three items were adapted from Taylor \& Bergman (1987). Sample item includes: "If I were searching for a job, I would apply to this organization".

Organizational Attributes. Three items were taken and adapted from Robertson, Collins and Oreg (2005). The items selected referred to the attributes of: career perspectives; adequate pay; training and development programs. Sample items include: "This organization would provide good career perspectives to its employees". Items were measured using a seven point scale from 1 (Highly Unlikely) to 7 (Highly Likely).

\section{Analytic Procedure Overview}

The Harman technique was performed to assure that the data don't account for significant amount of common method bias (Podsakoff, Mackenzie, Lee \& Podsakoff, 2003). After this procedure, we have tested our study hypotheses with SEM techniques (using AMOS 17.0), as they allow modeling structural relationships and yielding overall fit indices, while estimating mediational relationships ( $\mathrm{Hu} \&$ Bentler, 1999). Furthermore, as our study hypotheses expect moderated-mediated relations, SEM could be imple- mented (Preacher, Rucker \& Hayes, 2007), namely if having multi-group analysis to be performed.

For estimating model fit, we will report to the Root Mean Square Error of Approximation (RMSEA; Steiger \& Lind, 1980), Comparative Fit Index (CFI; Bentler, 1990), Tucker-Lewis Index (TLI; TuckerLewis, 1973) and $\chi^{2}$ values, providing a statistical basis for comparing the relative fit of models. Based on Browne and Cudeck (1989), Bollen and Stine (1990), Hu and Bentler (1999), Marsh, Kit-Tai and Wen (2004), we will consider models with CFI, TLI values $<.90$, and RMSEA values $>.10$ as deficient. Models with CFI, TLI values $>.90$ to $<.95$, and RMSEA values $<.08$ ranges as acceptable. Models with CFI, TLI values $>0.95$ and RMSEA values $\leq .06$ ranges will be considered to be very good.

Also, we have performed our SEM data analysis using bootstrapping technique (Efron, 1979) as it permits a re-sample distribution by calculating "the statistic of interest in multiple re-samples of the data set, and by sampling $n$ units with replacement from the original sample of $n$ units" (Preacher, Rucker \& Hayes, 2007, p.190). Several authors have been recommending the use of bootstrapping, notably, when using small to moderate samples (from 20 to 80 cases) to assess mediation (Efron \& Tibshirani, 1993). Bootstrapping tests are powerful as they detect that the sampling distribution of the mediated effect is skewed away from 0 (Shrout \& Bolger, 2002). Despite bootstrapping being well-known to statisticians and is incorporated in several data analysis programs, it does not fluently appear in organizational behavior literature. In regard to the characteristics of our sample and of the procedures required to fulfill our study purposes, we were encouraged by Bolger and Shrout (2002) recommendations regarding the data analysis benefits of using the bootstrap framework.

The analysis was carried out in three phases. First, we tested the goodness-of-fit of the proposed theoretical model and compared it with a single factor model. Second, we analyzed the mediation hypothesis. Third, we tested the structural parameters invariance of the proposed theoretical model in a multi-group analysis. For performing the multi-group analysis, we used the previously validated employer branding scenarios, according to which, three groups were built: positive, negative, neutral.

\section{Results}

Table 1 presents the descriptive statistics and the correlations between all the indicators used. As there are several strong and moderate correlations between the items used as indicators of the latent variables of the model, we compared the goodness-of-fit of the theoretical model with goodness-of-fit of a unifactorial solution. 
Table 1. Descriptive statistics and correlations

\begin{tabular}{lccccccccccc}
\hline Item & M & SD & 1 & 2 & 3 & 4 & 5 & 6 & 7 & 8 \\
\hline 1. Organizational Attributes 1 (OA1) & 4.88 & 1.26 & 1 & & & & & & \\
2. Organizational Attributes 2 (OA2) & 4.50 & 1.36 & $.517^{* *}$ & 1 & & & & & \\
3. Organizational Attributes 3 (OA3) & 4.95 & 1.44 & $.642^{* *}$ & $.498^{* *}$ & 1 & & & \\
4. Organizational Attractiveness 1 (ATT 1) & 4.62 & 1.62 & $.560^{* *}$ & $.470^{* *}$ & $.639^{* *}$ & 1 & & & \\
5. Organizational Attractiveness 2 (ATT 2) & 4.35 & 1.68 & $.574^{* *}$ & $.483^{* *}$ & $.606^{* *}$ & $.771^{* *}$ & 1 & & \\
6. Organizational Attractiveness 3 (ATT 3) & 4.37 & 1.77 & $.512^{* *}$ & $.452^{* *}$ & $.582^{* *}$ & $.767^{* *}$ & $.897^{* *}$ & 1 & \\
7. Intention to apply to a job vacancy 1 (IAJV 1) & 4.93 & 1.77 & $.492^{* *}$ & $.426^{* *}$ & $.530^{* *}$ & $.650^{* *}$ & $.715^{* *}$ & $.711^{* *}$ & 1 \\
8. Intention to apply to a job vacancy 2 (IAJV 2) & 4.91 & 1.78 & $.499^{* *}$ & $.380^{* *}$ & $.503^{* *}$ & $.630^{* *}$ & $.720^{* *}$ & $.708^{* *}$ & $.917^{* *}$ & 1 \\
9. Intention to apply to a job vacancy 3 (IAJV 3) & 4.78 & 1.86 & $.478^{* *}$ & $.399^{* *}$ & $.501^{* *}$ & $.650^{* *}$ & $.734^{* *}$ & $.715^{* *}$ & $.917^{* *}$ & $.896^{* *} 1$
\end{tabular}

Note. * variables intercorrelated at $p \leq .05 ; * *$ variables intercorrelated at $p \leq .01 ;$ OA $\alpha=.79 ;$ ATT $\alpha=.92 ;$ IAJV $\alpha=.96$;

In the theoretical model (Figure 2; Model 1), we have specified a direct path from organizational attributes (OA), and from organizational attractiveness (ATT) to IAJV. We have also specified a direct path from organizational attributes (OA) to organizational attractiveness (ATT). al non-significant paths) in the model having no direct path to be estimated (Model $1=\left(\chi^{2}(24)=36.678\right.$, $p \leq .05 ;$ RMSEA $=.051 ;$ CFI $=.993$; TLI $=.990$ ) (Alternative Model $=\left(\chi^{2}(25)=37.778, p \leq .05\right.$; RMSEA $=.050 ;$ CFI $=.993 ;$ TLI $=.990\left(\chi_{\text {difference }}^{2}\right.$ test=1.100 (1df) $p \leq .01)$. This evidence suggests a

Figure 2. Theoretical Model

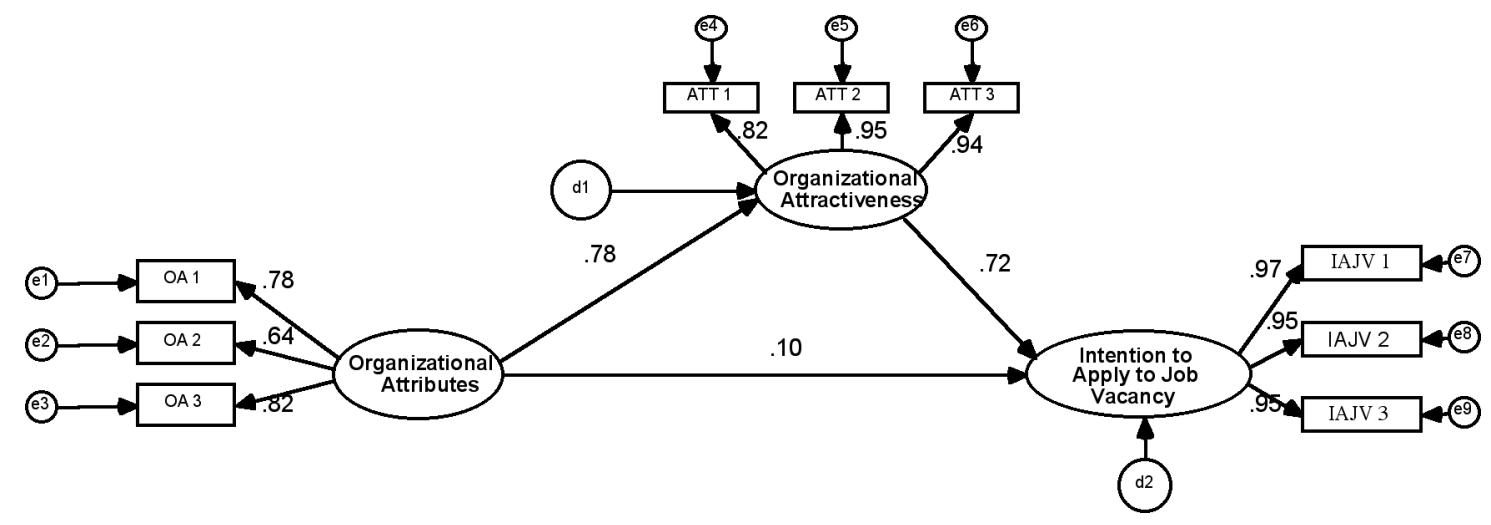

Analysis of the goodness-of-fit of the proposed model showed very good fit to the data $\left(\chi^{2}(24)\right.$ $=36.678, p \leq .05 ;$ RMSEA $=.05 ;$ CFI $=.99$; TLI $=.99)$. The alternative single factor model (model 2) has revealed unacceptable fit indices $\left(\chi^{2}(27)=400.786\right.$, $p \leq .05 ; \mathrm{RMSEA}=.259 ; \mathrm{CFI}=.80 ; \mathrm{TLI}=.73)$.

To evaluate mediational effects, we have first compared the fits of the theoretical model with the ones of an alternative model having no direct path to be estimated. We verified a slightly improved fit on the RMESA values (which is highly sensitive to addition- mediational effect of organizational attractiveness in the relation between the organizational attributes and IAJV. To see the magnitude on the mediational effects (if this mediation is either partial or total), we have followed the procedures commonly recommended for the analysis of mediation using structural equation models (Kenny \& Judd, 1984; Alwin and Hauser, 1975) and analysed the direct, indirect and total effects. Table 2 evidences the standardized total, indirect and direct effects for the mediational hypothesis validation purposes.

Table 2. Theoretical Model standardized total, indirect and direct effects.

\begin{tabular}{|c|c|c|c|}
\hline Path & $\begin{array}{c}\text { Total Effects } \\
(T . E .)\end{array}$ & $\begin{array}{l}\text { Indirect Effects (I.E.) } \\
\text { (via Attractiveness) }\end{array}$ & $\begin{array}{l}\text { Direct Effects } \\
\quad(D . E .)\end{array}$ \\
\hline Org. Attributes - IAJV & $.54 *$ & $.50^{*}$ & .04 n.s. \\
\hline
\end{tabular}


Table 3. Standardized Estimates of the baseline model in the different conditions.

\begin{tabular}{lccc}
\hline Path & Positive Condition & Neutral Condition & Negative Condition \\
\hline Org. Attributes - Attractiveness & .698 & .701 & .670 \\
Attractiveness - IAJV & .718 & .764 & .606 \\
Org. Attributes - IAJV & -.037 & -.148 & .213 \\
\hline
\end{tabular}

The direct effect of organizational attributes on IAJV is non-significant (Direct Effect $=.04 ; p>.05$ ), and the total effect of this predictor on IAJV is significant (Total Effect $=.54 ; p \leq .01$ ), as well as the indirect effect through organizational attractiveness (mediator) (Indirect Effect $=.50 ; p \leq .01$ ). These evidences constitute basis for total mediation of organizational attractiveness in the relation between organizational attributes and IAJV $\left(R^{2}=.64\right)$, confirming hypothesis one.

This result mean that the organizational attributes activates the process that leads prospective applicants to intent to apply to a job vacancy. It suggests that to attract job seekers within this professional field, information related to the organizational attributes should be a priority for recruiters.

We carried out the multi-group analysis to test the model invariance based on Byrne (2010) proposal. The groups we treated as the contextual moderators of our analysis. We aimed to clarify the hypothesis that the mediation effect of attractiveness in the relation between the organizational attributes and intention to apply is moderated by employer branding, and as such, we tested for the invariance of the structural relations along with the different employer branding groups.

We have previously guaranteed equivalence among the three employer branding groups regarding several criteria: size, gender, age, previous work experience, professionals and undergraduates. This assures that the multi-group comparisons results are not related to any kind of differences among the participants. The multigroup comparisons were performed with the joint analysis of a total of 208 participants (each employer branding group has the following number of participants: positive: 70 , neutral: 70, negative: 68). These sample characteristics are clearly fitted to the use of the bootstrapping technique (see Shrout \& Bolger, 2002).

In the matter of the multi-group analysis itself, we have first specified that the structural parameters would be freely estimated between the three employer branding conditions in the baseline model (Model 3). The goodness-of-fit of the baseline model is good $\left(\chi^{2}(72)\right.$ $=127.238, p \leq .05 ;$ RMSEA $=.061 ;$ CFI $=.962$; TLI $=.942$ ), and assures the metric invariance of our model.

Table 3 evidences the standardized estimates of the baseline model in the different employer branding conditions. This information is useful to understand the differences in the structural relations, showing the standardized estimates of the paths of the model, along the different conditions. Table 4 shows the baseline model standardized total, indirect and direct effects by each employer brand condition.

According to these evidences, there exists total mediational effect of organizational attractiveness in every employer branding condition. The effects differ along the different conditions (Positive (Total Effect $=.46, p \leq .01$; Indirect Effect $=.50, p \leq .01 ;$ Direct Effect $=-.04$, n.s. $) /$ Neutral (Total Effect $=.39, p \leq .01$; Indirect Effect $=.54, p \leq .01 ;$ Direct Effect $=-.15$, n.s. $) /$ Negative (Total Effect $=.62, p \leq .01$; Indirect Effect $=.41, p \leq .01$; Direct Effect $=.21$, n.s.). The variation of the strength of the effects within the different image conditions was clear. The question that remained to answer was if these differences introduced meaningful statistically differences and where the differences have stronger magnitude. Then, following our analysis, we have constrained the parameters of the structural model to assume equality between the different employer branding conditions.

Results indicate that the fit of the model where all employer brand groups were constrained on $1^{\text {st }}, 2^{\text {nd }}$ and $3^{\text {rd }}$ order paths (Model 4) is worse than the baseline model $\left(\right.$ Model $4=\left(\chi^{2}(79)=143.828, p \leq .05\right.$; RMSEA $=.063 ; \mathrm{CFI}=.955 ; \mathrm{TLI}=.938)$ and based on the $\chi^{2}$ difference test, statistically different $\left(\chi^{2}\right.$ difference test $=16.590$ (7df) $p \leq .01$ ), which enables us to reject the invariance of the structural model along with the different conditions.

Table 4. Baseline Model total, indirect and direct effects for moderated-mediation

\begin{tabular}{lccc}
\hline Condition & $\begin{array}{c}\text { Total Effects } \\
\text { (T.E.) }\end{array}$ & $\begin{array}{c}\text { Indirect Effects (I.E.) } \\
\text { (via Attractiveness) }\end{array}$ & $\begin{array}{c}\text { Direct Effects } \\
(\text { D.E.) }\end{array}$ \\
\hline Positive Employer Brand & $.46^{*}$ & $.50^{*}$ & -.04 n.s. \\
Neutral Employer Brand & $.39 *$ & $.54 *$ & -.15 n.s. \\
Negative Employer Brand & $.62 *$ & $.41^{*}$ & .21 n.s. \\
\hline
\end{tabular}

Dependant variable: Intention to Apply to a Job Vacancy(IAJV)

Factor: Organizational Attributes

$* p \leq .01$ 
Table 5. Summary of SEM Analyses for moderated-mediation effects

\begin{tabular}{|c|c|c|c|c|c|c|}
\hline \multirow[b]{2}{*}{ Models } & \multicolumn{5}{|c|}{ Fit Indices } & \multirow[b]{2}{*}{ TLI } \\
\hline & DF & $\chi^{2}$ & $\chi_{\text {difference }}^{2}(\mathbf{D F})$ & RMSEA & CFI & \\
\hline M1: Theoretical Model & 24 & $36.678^{*}$ & & .051 & .993 & .990 \\
\hline M2: Single factor model & 27 & $400.786^{*}$ & $364.108(3)^{*}$ & .259 & .796 & .728 \\
\hline M3: Baseline Model & 72 & $127.238 *$ & & .061 & .962 & .942 \\
\hline M4: All groups constrained on $1^{\text {st }}, 2^{\text {nd }}$ and $3^{\text {rd }}$ order paths & 80 & $144.032 *$ & $16.794(8)^{*}$ & .062 & .956 & .940 \\
\hline M5: All groups constrained on $1^{\text {st }}$ and $3^{\text {rd }}$ order paths & 77 & $142.097 *$ & $14.859(5)^{*}$ & .064 & .955 & .937 \\
\hline M6: All groups constrained on $2^{\text {nd }}$ and $3^{\text {rd }}$ order paths & 77 & $138.531 *$ & $11.293(5)^{*}$ & .062 & .957 & .940 \\
\hline M7: All groups constrained on $1^{\text {st }}$ and $2^{\text {nd }}$ order paths & 77 & $131.807 *$ & $4.569(5)$ & .059 & .962 & .947 \\
\hline $\begin{array}{l}* p \leq .05 \\
\text { Notes: } N=208 ; \\
\text { Bootstrapping with sampling }=1000\end{array}$ & & & & & & \\
\hline
\end{tabular}

This means that employer branding moderates the mediational effect of attractiveness in the relation between the organizational attributes and intention to apply.

In order to gain specificity in understanding exactly where does the influence of employer branding occurs, we verified if the invariance of the structural model could be rejected when all groups were constrained to equality on $1^{\text {st }}$ and $3^{\text {rd }}$ order paths, $2^{\text {nd }}$ and $3^{\text {rd }}$ order paths, and $1^{\text {st }}$ and $2^{\text {nd }}$ order paths (Models 5 to 7 ). We verified that the fits of models five and six were worse than the one of the baseline model and statistically different (Model $5=\left(\chi^{2}(77)=142.097, p \leq .05\right.$; RMSEA $=.064 ; \mathrm{CFI}=.955 ; \mathrm{TLI}=.937\left(\chi^{2}\right.$ difference test $=14.859$ (5df) $p \leq .01) /\left(\right.$ Model $6=\left(\chi^{2}(77)=138.531, p \leq .05\right.$; RMSEA $=.062 ;$ CFI $=.957 ;$ TLI $=.940\left(\chi^{2}\right.$ difference test $=11.293(5 \mathrm{df}), p \leq .01)$, which provides evidences of moderation. Model seven also evidences moderation effect. The statistical difference between the baseline model and model seven is non-significant (Model $7=$ $\left(\chi^{2}(77)=131.807, p \leq .05 ;\right.$ RMSEA $=.059 ; \mathrm{CFI}=.962$; TLI $=.947\left(\chi^{2}\right.$ difference test $=4.569$ (5df), n.s. $)$. In this case, the constrained model has better fit when compared with the baseline, and presents more degrees of freedom for explaining the structural relations. This gives basis for rejecting the invariance of the structural relations when all groups were constrained to equality on $1^{\text {st }}$ and $3^{\text {rd }}$ order paths, $2^{\text {nd }}$ and $3^{\text {rd }}$ order paths, and $1^{\text {st }}$ and $2^{\text {nd }}$ order paths.

Also, we have compared the statistical difference between the model four (all branding groups constrained on $1^{\text {st }}, 2^{\text {nd }}$ and $3^{\text {rd }}$ order paths) and model seven (as this was the best fitted model), in order to clarify the magnitude of the strength of the $3^{\text {rd }}$ order path to introduce the variance in the structural relations. The models four and seven differ significantly $\left(\chi^{2}\right.$ difference test $\left.=12.225(3 \mathrm{df})\right)$, having model seven the best fit indices. This shows that the rejection of the invariance of the structural model is due to the differences verified on the path between the organizational attributes and intention to apply ( $3^{\text {rd }}$ order path). The process that leads to IAJV is stronger when prospective applicants have a positive employer branding of the organization, especially due to the magnitude of the direct effects evidenced in this condition. This result means that the hypothesis two is confirmed, as the mediation effect of attractiveness in the relation between the organizational attributes and intention to apply to a job vacancy is moderated by employer branding. A positive employer branding has resulted is a stronger process leading prospective applicants to IAJV. The employer brand constrains the applicants' job searching process.

\section{Discussion}

Research on the relationship between the organizational attributes and important indicators of the attraction stage of a recruitment process has strong support for explaining prospective applicants' attitudes and intentions (Cable \& Judge, 1994; Lievens, Decaesteker, Coetsier \& Geirnaert, 2001; Lievens, Van Hoye $\&$ Schreurs, 2005). This has resulted in viewing the organizational attributes as one of the most used factors to explain prospective applicants' job searching behaviour when they are called to evaluate job vacancies. Having the theoretical guidance offered by the Theory of Reasoned Action, our first purpose was to validate a theoretical model integrating the organizational attributes, attractiveness and IAJV, in which we supported that organizational attractiveness acts as a mediator of the relation between the organizational attributes and IAJV. Also, several empirical evidences point for the relevance of employer branding, notably, its dimensions on organizational attraction (Lievens \& Highhouse, 2003; Reeve, Highhouse \& Brooks, 2006; Ryan, Horvath \& Kriska, 2005; Turban \& Greening, 1997).

Following our review of literature, main research options in this field have not clarified in what way employer branding constrains job seekers attitudes and 
behaviors. As such, it was unclear how or if employer branding constrains applicants job searching processes. This clarification was relevant, due to insufficient research approaching this specific problem of investigation. Understanding its influence in applicants' job searching process was our strong purpose of research. Fulfilling these aims meant approaching the study of applicants' attraction to organizations integrating a process and a context, through a moderated-mediation expected effect.

Our data was analysed in several stages. Our results reinforce evidences assuring centrality of the organizational attributes in this area of research (Lievens, Van Hoye \& Schreurs, 2005) and add the value of validating a theoretical model that sustains that the IAJV is a result of a process that starts on the organizational attributes, and is mediated by organizational attractiveness perception. We believe this to be a very important advance for existing research, as this study has had a confirmatory nature, and was build based mostly on clues retrieved from studies in this field of research that had a more exploratory nature (Carless, 2005; Porter, Conlon \& Barber, 2004).

To evaluate the influence of employer branding in this applicants' process, we have followed a procedure based on Byrne (2010). Our results showed that employer brand constrains the process that leads prospective applicants to the intention of deciding to apply to a vacancy, which leads us to reject the invariance of the structural model along with the different employer branding conditions. We also found that the rejection of the invariance of the structural model is strongly related to the differences verified on the path between the organizational attributes and intention to apply to a job vacancy. We conclude that a positive employer branding of the organization strengthens the process that leads to IAJV and that this process is weaker when applicants have a negative employer brand assessment of the organization.

These conclusions have some echo in existing clues retrieved in literature, which indicate that employer branding dimensions are relevant for explaining organizational attraction (Reeve, Highhouse \& Brooks, 2006; Turban \& Greening, 1997). The results of this study could bring added knowledge from an empirical, theoretical, and also in a practical perspective, as the empirical clarification of employer branding to constrain applicants' attitudes and behaviours is a key outcome.

On the empirical point of view, this study gives an important step towards validating a theoretical process model that explains how IAJV is generated. It also shows how branding acts in this process, evidencing how it constrains the process and how it strengthens it. Our results indicate that organizational attractiveness is a key-variable in the attraction stage of a recruitment process, by having a mediating role in predicting IAJV, when prospective applicants evaluate a job vacancy. They also show that employer brand has a moderator role in this process, revealing its importance and centrality in the attraction stage. These results extend existing empirical knowledge in the field of organizational attraction (Lievens, Van Hoye \& Schreurs, 2005), by validating this theoretical model, and by explaining applicants' attraction to organizations integrating a process and a context in a moderated-mediation model of analysis.

From a theoretical point of view, job choice and organizational attraction literatures may add information to existing models in these areas of research. This assumption is made based on the clarification of the status of organizational attractiveness perception and of the employer branding for generating IAJV, as central elements of the attraction stage of a recruitment process. By validating our theoretical model, future research opportunities may be stimulated.

From a practical point of view, this study results give directions to improve prospective applicants' attraction, and to improve recruitment efficacy. Human resource managers should be aware that, when advertising for a job vacancy, prospective applicants will give importance to the organizational attributes. We recommend that recruitment messages in employment ads to give focus on the organizational attributes elements, as it will more likely predict attractiveness perception, and determining job seekers' IAJV. The same way, employer branding is a key element in this process, as it can constrain it. Employment ads should also give focus on the several dimensions of the employer brand construct, as it will strengthen the process that generates applicants' IAJV. A positive employer branding should give strong contributes for this process, as it strengthens it, and, so, recruiters should make efforts for generating positive inputs on prospective applicants, by enlightening its several dimensions when advertising for the job vacancy. For these reasons, recruiters' concerns should focus on ways to improve the awareness of the employer branding on job seekers.

\section{Study limitations and future research suggestions}

The main conclusions as well as the theoretical, empirical and practical implications of this study should be read with some conditionings. An important issue is that despite all the data collection procedures, the diversified statistical procedures, and the methods and efforts to minimize and to control systematic common method errors, this study may not be fully immune to them. Another relevant issue is that along with the study we have present several ideas that may encourage assuming causality between variables. We should make clear that although we have presented a model of analysis with variables working as cause and as effect, 
causality was theoretically driven. Alternative sets of interpretation may be possible to assume.

We suggest the replication of this study within other professional profiles, in order to verify if these results maintain its stability among samples with different characteristics. Additional researches focused on clarifying the stability of these results are very welcomed, specifically if made on diversified prospective applicants' profiles. In addition, we also think that replicating this study using different kinds of age-groups to be valuable, as it is important to establish if these results maintain their stability. We consider these results to be relatively stable as we have controlled the influence of age on our dependant variable and saw no effects. Additionally, existing research seems to have pointed that, when compared to job-related factors in employment ads, the organizational attributes gather similar kinds of evaluations (see Gomes \& Neves, 2010). As we can see, future replications on this study are needed and very welcomed, as this is an important clarification to address.

As a way of introducing advances, we think that integrating different theoretical framings in this field of research should be looked as a challenge that could bring significant added-value. For instance, the perspectives brought by interactionist frames combined with behaviourist approaches of the attraction stage of a recruitment process, are likely to result in richer theoretical reasoning for supporting deeper understanding of this area of research. For example, if the variables used in our model of analysis were to be integrated with variables used in different theoretical framing, such as P-O Fit, our reasoning of organizational attraction is likely to be improved. Considering this argumentation, the status of $\mathrm{P}-\mathrm{O}$ fit is uncertain in our moderated-mediation model, and may be relevant to consider its pertinence of integrating it for future research. Clarifying its status in the proposed theoretical model may contribute to important theoretical, empirical and practical added-value.

\section{References}

Aiman-Smith, L., Bauer, T. \& Cable, D. (2001) Are you attracted? Do you intend to pursue? A recruiting policycapturing study. Journal of Business and Psychology, 16, 219-237.

Albarracín, D., Fishbein, M., Johnson, B. \& Muellerleile, O. (2001). Theories of reasoned action and planned behaviour as models of condom use: A meta-analysis. Psychological Bulletin, 127, 142-161.

Alwin, F., \& Hauser, R. (1975). The decomposition of effects in path analysis. American Sociological Review, $40,37-47$

Ambler, T. \& Barrow, S. (1996). The employer brand. Journal of Brand Management, 4, 185-206.

Anderson, J. \& Gerbing, D. (1988). Structural equation in practice: a review and recommended two-step approach. Psychological Bulletin, 103, 411-423.

Backhaus, K. (2004). An exploration of corporate recruitment descriptions on Monster.Com. The Journal of Business Communication, 41, 115-137.

Backhaus, K., Stone, B., Heiner, K., (2002). Exploring the relationship between corporate social performance and employer attractiveness. Business and Society, 41, 292318.

Barber, A. (1998). Recruiting employees: Individual and organizational perspectives. Thousand Oaks, CA: Sage Publications.

Bauer, T., \& Aiman-Smith, L (1996). Green career choices: The influence of ecological stance on recruiting. Journal of Business and Society, 10, 445-458.

Bentler, P. (1990). Comparative fit indexes in structural models. Psychological Bulletin, 107, 238-246.

Bollen, K. \& Stine, R. (1990). Direct and indirect effects: classical and bootstrap estimates of variability. Sociological Methodology, 20, 115-140

Breaugh, J. A. (1992). Employee Recruitment: Theory and Practice. Boston: PWS-Kent Publishing.

Bretz, R., Ash, R. \& Dreher, G. (1989). Do people make the place? An examination of the attraction-selection-attrition hypothesis. Personnel Psychology, 42, 561-581.

Browne, M., \& Cudeck, R. (1989). Single sample cross-validation indexes for covariance structures. Multivariate Behavioral Research, 24, 445-455.

Byrne, B. (2010). Structural equation modeling with AMOS: basic concepts, applications, and programming $\left(2^{\text {nd }}\right.$ edition). New York: Routledge. Taylor \& Francis Group.

Cable, D., \& Judge, T. (1994). Pay preferences and job decisions: a person-organization fit perspective. Personnel Psychology, 47, 317-348.

Cable, D. \& Turban, D. (2001). Establishing the dimensions, sources and value of job seekers employer knowledge during recruitment. In G. R. Ferris (Ed.), Research in personnel and human resources management, 115-163. New York: Elsevier Science.

Cable D., \& Yu, K. (2006). Managing job seekers' organizational image beliefs: the role of media richness and media credibility. The Journal of applied psychology, 91, 828-40.

Carless, S. (2005). Person-job fit versus person-organization fit as predictors of organizational attraction and job acceptance intentions: A longitudinal study. Journal of Occupational and Organizational Psychology, 78, 411-429.

Chapman, D., Uggerlev, K., Carroll, S., Piasentin, K. \& Jones, D. (2005). Applicant attraction to organizations and job choice: a meta-analytic review of the correlates of recruiting outcomes. Journal of Applied Psychology, 90, 928-944.

Collins, C., \& Han, J. (2004). Exploring applicant pool quantity and quality: the effects of early recruitment practices, corporate advertising and firm reputation. Personnel Psychology, 57, 685-717.

Davies, G. (2007). Employer branding and its influence on managers. European Journal of Marketing, 42, 667-681. 
Efron, B. (1979) Bootstrap methods: another look at the jackknife. The Annals of Statistics, 7, 1-26.

Efron, B., \& Tibshirani, R. (1993). An introduction to the bootstrap. New York: Chapman \& Hall/CRC.

Fishbein, M., \& Ajzen, I. (1975). Belief, attitude, intention and behaviour: An introduction to theory and research. Reading, MA: Addison-Wesley.

Fombrun, C. \& Shanley, M. (1990). What's in a name? Reputation-building and corporate strategy. Academy of Management Journal, 33, 233-258.

Gatewood, R., Gowan, M. \& Lautenschlager, G. (1993). Corporate image, recruitment image, and initial job decisions. Academy of Management Journal, 36, 414-427.

Gomes, D. \& Neves, J. (2010). Do applicants' prior experiences influence organizational attractiveness prediction? Management Research: The Journal of the Iberoamerican Academy of Management, 8, 203-220.

Gomes, D. \& Neves, J. (in press). Organizational attractiveness and prospective applicants' intentions to apply. Personnel Review.

Highhouse, S., Lievens, F. \& Sinar, E. (2003). Measuring attraction to organizations. Educational and Psychological Measurement, 63, 986-1001.

Highhouse, S., Stanton, J. M. \& Reeve, C. (2004). Examining reactions to employer information using a simulated web-based job fair. Journal of Career Assess-ment, 12, 85-96.

Hu, L. \& Bentler, P. (1999). Cutoff Criteria for fit indexes in covariance structure analysis: conventional criteria versus new alternatives. Structural Equation Modeling, 6, 1-55.

Jackson, S., Schuler, R. \& Rivero, J. (1989): Organization characteristics as predictors of personnel practices. Personnel Psychology, 42, 727-786.

Judge, T. \& Cable, D. (1997). Applicant personality, organizational culture, and organization attraction. Personnel Psychology, 50, 359-394.

Kenny, D. A., \& Judd, C. M. (1984). Estimating the nonlinear and interactive effects of latent variables. Psychological Bulletin, 96, 201-210.

Kickul, J. (2001). Promises made, promises broken: An exploration of small business attraction and retention practices. Journal of Small Business Management, 39, 320-335.

Lievens, F., Decaesteker, C., Coetsier, P. \& Geirnaert, J. (2001). Organizational attractiveness for prospective applicants: a person-organization fit perspective. Applied Psychology: An international review, 5, 30-51.

Lievens F. \& Highhouse, S. (2003). The relation of instrumental and symbolic attributes to a company's attractiveness as an employer. Personnel Psychology, 56, 75-102.

Lievens, F., Van Hoye, G. \& Schreurs, B. (2005). Examining the relationship between employer knowledge dimensions and organizational attractiveness: An application in a military context. Journal of Occupational and Organizational Psychology, 78, 553-572.

Lievens, F., Van Hoye, G. \& Anseel, F. (2007). Organizational identity and employer image: towards a unifying framework. British Journal of Management, 18, 545-559.
Luce, R., Barber, A. \& Hillman, A. (2001). Good deeds and misdeeds: a mediated model of the effect of corporate social performance on organizational attractiveness. Business and Society, 40, 397-415.

Mark, P. \& Toelken, K. (2009). Poisoned by a toxic brand: a worst case scenario of employer branding - a case study of a Fortune 100 Technology Firm. Organizational Development Journal, 27, 21-30.

Marsh, H., Hau, K. \& Wen, Z., (2004). In search of golden rules: Comment on hypothesis testing approaches to setting cutoff values for fit indexes and dangers in overgeneralising $\mathrm{Hu} \&$ Bentler's (1999) findings. Structural Equation Modelling, 11, 320-341

Maurer, S. D., Howe, V. \& Lee, T. W. (1992). Organizational recruiting as marketing management: An interdisciplinary study of engineering graduates. Personnel Psychology, 45, 807-833.

Petty, R. \& Cacioppo, J. (1986). The elaboration likelihood model of persuasion. In L. Berkowitz (Ed.), Advances in experimental social psychology, 123-205. Orlando, FL: Academic Press.

Podsakoff, P., Mackenzie, S., Lee, J. \& Podsakoff, N. (2003). Common method biases in behavioural research: a critical review of the literature and recommended remedies. Journal of Applied Psychology, 88, 879-903.

Porter, C., Conlon, D. \& Barber, A. (2004). The dynamics of salary negotiations: effects on applicants' justice perceptions and recruitment decisions. The International Journal of Conflict Management, 15, 273-303.

Powell, G. (1984). Effects of job attributes and recruiting practices on applicant decisions: a comparison. Personnel Psychology, 37, 721-732.

Preacher, K., Rucker, D. \& Hayes, A. (2007). Addressing moderated mediation hypotheses: theory, methods and prescriptions. Multivariate Behavioral Research, 42, 185-227.

Reeve, C., Highhouse, S. \& Brooks, M. (2006). A closer look at reactions to realistic recruitment messages. International Journal of Selection and Assessment, 14, 1-15.

Robertson, Q., Collins, C. \& Oreg, S. (2005). The effects of recruitment message specificity on applicant attraction to organizations. Journal of Business and Psychology, 19, 319-339.

Ryan, A., Horvath, M. \& Kriska, S. (2005). The role of recruitment source informativeness and organizational perceptions in decisions to apply". International Journal of Selection and Assessment, 13, 235-249.

Rynes, S, Bretz, R. \& Gerhart, B. (1991). The importance of recruitment in job choice: A different way of looking. Personnel Psychology, 44, 487-521.

Saks, A., Leck, J., \& Saunders, D. (1995). Effects of application blanks and employment equity on applicant reactions and job pursuit intentions. Journal of Organizational Behaviour, 16, 415-430.

Schneider, B. (1987). The people make the place. Personnel Psychology, 40, 437-453.

Shrout, P. \& Bolger, N. (2002). Mediation in experimental and nonexperimental studies: new procedures and recommendations. Psychological Methods, 7, 422-445. 
Spence, M. (1973). Job market signalling. Quarterly Journal of Economics, 87, 355-374.

Steiger, J. \& Lind, J. (1980). Statistically based tests for the number of common factors. Paper presented at the annual meeting of Psychometric Society, IOWA, IA.

Taylor, M. \& Bergman, T. (1987). Organizational recruitment activities and applicants reactions at different stages of the recruitment process. Personnel Psychology, 40, 261-285.

Thomas, K. \& Wise, G. (1999). Organizational attractiveness and individual differences: Are diverse applicants attracted by different factors? Journal of Business and Psychology, 13, 375-397.

Tom, V. (1971). The role of personality and organizational images in the recruiting process. Organizational Behaviour and Human Performance, 6, 573-592.

Tucker, L. \& Lewis, C. (1973). A reliability coefficient for maximum likelihood factor analysis. Psychometrika, 38, 1-10.
Turban, D. \& Greening, D. (1997). Corporate social performance and organizational attractiveness to prospective employees. Academy of Management Journal, 40, 658672.

Turban, D. \& Keon, T. (1993). Organizational attractiveness: An interactionist perspective. Journal of Applied Psychology, 78, 184-193.

Van Hooft, J., Born, M., Taris, T., \& Van der Flier, H. (2006). Ethnic and gender differences in applicants' decisionmaking processes: An application of the theory of reasoned action. International Journal of Selection and Assessment, 14, 156-166.

Wanous, J. (1992). Organizational Entry: Recruit-ment, Selection and Socialization ofewcomers. 2nd ed., Prentice Hall, Upper Saddle River, NJ.

Williams, M., \& Bauer, T. (1994). The effect of managing diversity policy on organizational attractiveness. Group \& Organizational Management, 19, 295-308.

Manuscript received: 05//8/2010

Review received: 23/11/2010

Accepted: 25/11/2010 